\title{
THE EFFECT OF THE IMPLEMENTATION OF CHAT ROOM-BASED BLENDED LEARNING ON STUDENTS' MOTIVATION AND LEARNING OUTCOMES
}

\author{
Muhibbuddin $^{1^{*}}$, Agusriati Muliyana $^{2}$, Djufri $^{3}$, Hasanuddin ${ }^{4}$ \\ ${ }^{1}$ Dr, Syiah Kuala University, Banda Aceh, Indonesia, muhibbuddin@unsyiah.ac.id \\ ${ }^{2}$ Syiah Kuala University, Banda Aceh, Indonesia, agusriatimuliyana.mpbio18@edu.unsyiah.ac.id \\ ${ }^{3} \mathrm{Dr}$, Syiah Kuala University, Banda Aceh, Indonesia, djufri@fkip.unsyiah.ac.id \\ ${ }^{4} \mathrm{Dr}$, Syiah Kuala University, Banda Aceh, Indonesia, hasanuddin@fkip.unsyiah.ac.id \\ ${ }^{*}$ Corresponding Author
}

\begin{abstract}
Motivation and good learning outcomes are important aspects that students must have. Several studies show that students have low motivation and learning outcomes. It is necessary to improve the learning model to overcome this problem. One of the efforts that can be taken is the application of the Chat Roombased Blended Learning model. This study aims to determine the effect of the application of the Chat Roombased Blended Learning model on student motivation and learning outcomes in the human respiratory system material. This is a Quasi-Experimental design with a Pretest-Posttest Non-Equivalent Control Group Design model. The research subjects were 68 students who were divided into two groups (experimental and control) where each group consisted of 34 students. The experimental group used the Chat Room-based Blended Learning model, while the control group learning was carried out using the Blended Learning model. This research was conducted at a high school in Meulaboh, West Aceh Regency, Indonesia. This research was conducted for two months (January-February 2020). The data collection parameters in this study were the learning outcomes and student motivation. Data collection was carried out through pretest and posttest. The test for differences in learning motivation and learning outcomes was analyzed using parametric statistics, namely the ANACOVA test. The results showed that the application of the chat room-based blended learning model had a positive contribution to increasing student motivation and learning outcomes. There needs to be a further study of the learning process with a chat room-based blended learning model.
\end{abstract}

Keywords: Blended Learning, Motivation, learning outcomes.

\section{INTRODUCTION}

Many factors influence the low motivation and student learning outcomes. Learning motivation plays an important role for students and teachers because it determines the extent of their participation in the learning process (Vanslambrouck et al., 2018).

In addition to providing an understanding of the importance of learning, teachers must know the motivation that is needed or can be given to students (Vanslambrouck et al., 2018). Therefore, it is necessary to have further research on how to shape learning motivation to influence student learning outcomes. Learning outcomes are a form of behavior change after efforts to increase knowledge or explore one's potential. Acquisition of aspects of behavior change depends on what students learn. It means that learning outcomes can be seen from attitudes, skills, and knowledge after the learning process (Eliseev, 2016).

The results of observations and interviews in several high schools in Meulaboh show that many students have not reached the minimum completeness of learning, namely 75 . The average student only gets 65-73. 
Besides that, it also shows the low learning completeness, motivation, and student learning outcomes.

The average result of the 2015 National Examination was 65.78, decreasing to 53 in 2018. The average national exam score in Biology in Aceh Province was 52.16. Meulaboh is the capital city of West Aceh district, Aceh province, Indonesia. The district exam score is ranked 16 out of 23 districts in Aceh (Anonymous, 2018) with an average of 43.01. The low average result of the National Examination in Meulaboh shows that student learning motivation is not yet optimal so that it affects learning outcomes. One of the efforts made by the Meulaboh Regency Government to increase student motivation and learning outcomes is to apply an appropriate learning model during the learning process.

On the other hand, ICT and the internet allow the implementation of the learning process anytime and anywhere. Gros and García-Peñalvo (2016) show a shift in the learning process due to the development of information technology, such as training to performance, from classrooms to anywhere and anytime, from paper to digital, from physical facilities to network facilities, from cycle-time to real-time.

There needs to be an innovation in the learning process to solve the above problems. One solution that can be taken is the application of blended learning. Blended learning is a hybrid learning model (a combination of an instruction model with two / more learning strategies). In the 1960s, many programs relied on the internet to deliver digital learning material to students. For example, programmed logic for automatic operation teaching was developed at the University of Illinois (Lu, et al., 2018). In recent years, blended learning has become a popular learning model due to the development of data analysis and calculations, for example, the integration of social networks into one semester programs and monitoring the behavior of more than 220 engineering students (Lu et al., 2018).

Alsalhi et al. (2019) and Dziuban et al. (2018) show that blended learning improves science learning outcomes and affects student attitudes in the learning process. Besides, the blended learning model can improve student access to information sharing in the learning process and show good results. Chandra \& Fisher (2009); Chen \& Jones (2007); Kavitha \& Jaisingh (2018); Kintu \& Zhu (2016); and Yeh at al. (2011) revealed the ease, flexibility, and effectiveness of learning using WEB-based blended learning which can increase student independence and create positive interactions between students during learning. Blended learning can help students to plan learning and update information (Smyth et al., 2012). However, the effect of the application of the chat room-based blended learning model on student motivation and learning outcomes are not well known. Research is needed to determine the effect of the application of the chat room-based blended learning model on student motivation and learning outcomes.

\section{RESEARCH METHODOLOGY}

This is a Quasi-Experimental Research with a Pretest-Posttest Non-Equivalent Control Group design. The study design is described in Table-1 (Gall et al., 2003).

Tabel-1. Pretest-Posttest Non-Equivalent Control Group Design

\begin{tabular}{|c|c|c|c|c|}
\hline Sample & Group & Pretest & Treatment & Post-test \\
\hline Not random & Experiment & P1 & X1 & P2 \\
\hline Not random & Control & K1 & X2 & K2 \\
\hline
\end{tabular}

Description:

A: treatment

B: control

$\mathrm{P}_{1}$ : pre-test score (before treatment)

$\mathrm{P}_{2}$ : post-test score (after treatment)

$\mathrm{K}_{1}$ : Experimental group consists of class $\mathrm{X} 1-1$

$\mathrm{K}_{2}$ : Control group consists of class $\mathrm{X} 1-2$

$\mathrm{X}_{1}$ : chat room-based blended learning model treatment

$\mathrm{X}_{2}$ : blended learning treatment

The research subjects were 68 students who were selected purposively from 105 students in one high 
school. The research subjects were divided into two groups (experimental and control groups). Each group consisted of 34 students who were not randomly selected. The experimental group carried out learning using chat room-based blended learning while the control group used blended learning. The research was conducted in January-February 2020 at one of the high schools in West Aceh Regency, Indonesia.

The parameters of data collection in this study were motivation and learning outcomes. The motivation was measured using a closed questionnaire instrument while learning outcomes were measured using 60 multiple choice test items. The content and construction of the instruments used in data collection were validated (Hake, 2007).

\section{DATA AND ANALYSIS}

Learning motivation data is calculated using the percentage aspects of Attention, Relevance, Confidence, and Satisfaction (ARCS) from the student learning motivation questionnaire. Furthermore, ordinal data (student motivation data) is converted into interval data using the Interval Successive Method (ISM), while student learning outcomes are analyzed using covariance analysis (ANCOVA) to test the significance of learning outcomes between the experimental group and the control group.

\section{RESULT AND DISCUSSION}

\subsection{Results of Student Learning Motivation}

The experimental and control groups learning motivation data in Table-2 shows three categories of learning motivation (very high, high, and moderate). 20 students of the experimental group were in the very high category (59\%) and the other 14 students were in the high category (51\%). On the other hand, 13 control group students were in the very high category (38\%), 20 students entered the high category (59\%), and 1 student entered the moderate category (3\%).

Table-2. Student motivation category

\begin{tabular}{|c|c|c|c|}
\hline \multirow{2}{*}{ No } & \multirow{2}{*}{ Student motivation category } & \multicolumn{2}{|c|}{ Number of students } \\
\cline { 3 - 4 } & Low & Experiment & Control \\
\hline 1 & Moderate & - & - \\
\hline 2 & High & $14(51 \%)$ & $20(59 \%)$ \\
\hline 3 & Very high & $20(59 \%)$ & $13(38 \%)$ \\
\hline 4 & & - & $13 \%)$ \\
\hline
\end{tabular}

The experimental group had more students with very high motivation than the control group. This shows that the application of chat room-based blended learning has a positive impact on student learning motivation. Meanwhile, the application of blended learning in the control group did not have a good impact on student learning motivation.

The results of the analysis of student learning motivation using the Interval Successive Method (MSI) show that each category of learning motivation (Figure-1) measured using the ARCS indicator has a different percentage of influence between the experimental and the control groups.

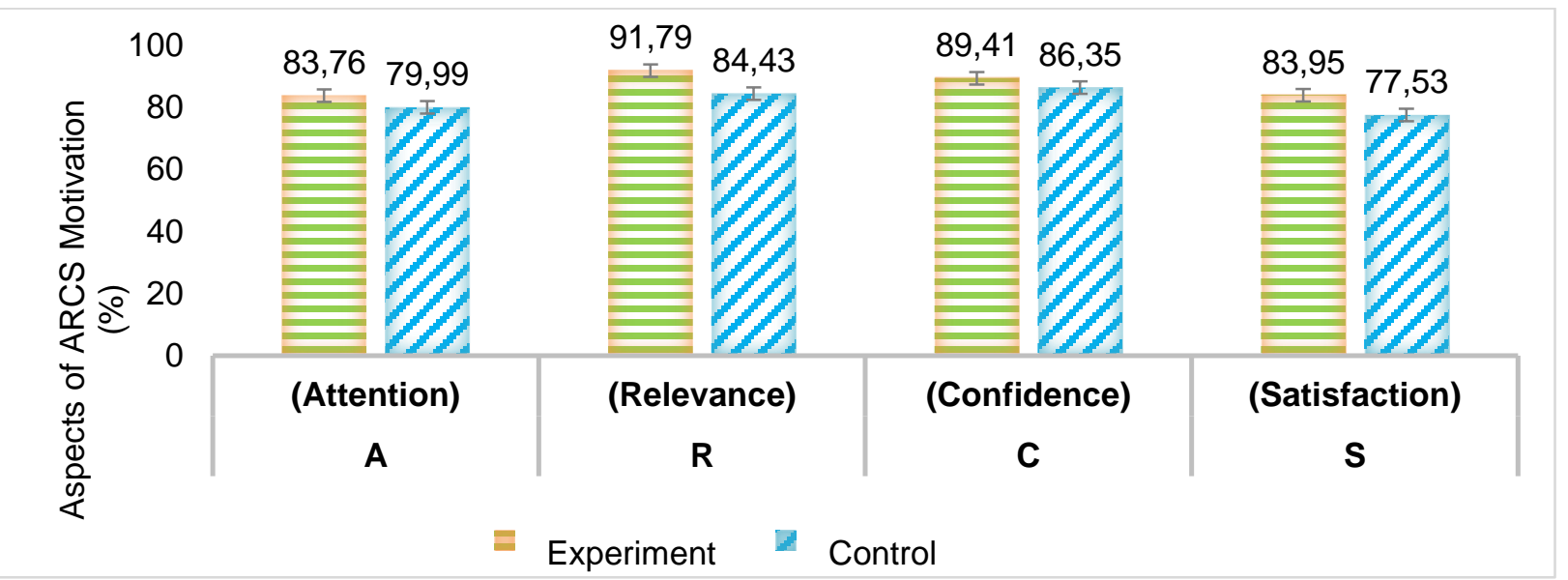

Figure-1. Percentage of student motivation for each ARCS aspect 
The analysis based on the ARCS aspect shows that the experimental group gets the highest percentage of all aspects (attention $83.76 \%$, relevance $91.79 \%$, confidence $86.35 \%$, and satisfaction $83.95 \%$ ). The aspect of attention was the lowest in the experimental group, while satisfaction was the lowest in the control group. The high motivation to learn in the student experimental group shows that the application of chat room-based blended learning contributes positively to their learning motivation. The difference in learning motivation between experimental and control groups indicates that the application of chat room-based blended learning can increase student learning motivation. Previous studies have also shown that Web-based or E-learning blended learning using computers, tablets, or phones connected to the internet allows students to study anywhere and anytime (Aleksander et al., 2017).

Students have a pretty good driving force when they learn to use chat room-based blended learning. Motivation refers to attitude and action when it comes to learning. Some students seemed enthusiastic to respond in the chat room. They ask and respond to every material shared by the researchers. The online learning process also runs well in the experimental group where students show their participation by responding and asking various questions related to assignments and questions that are shared online. Responses allow students to understand and do assignments well. This can be seen during the presentation process to each group, where each group can explain their respective material well. Each student can understand the material of the respiratory system completely and it was represented from the high learning outcomes of the experimental group students. Blended learning can increase student motivation and learning outcomes on the elemental periodic system material (Huang et al., 2016). Internet-based blended learning can add to the learning experience, knowledge, and variations in learning models. It can also increase freedom, independence, motivation, and student interest in learning (Rasmitadila, 2020). The use of web-based or application-based e-learning can increase motivation and learning performance, and accelerate feedback from students and educators (Huang et al., 2016)

\subsection{Students' Learning Outcomes}

Figure-2 shows the means of the pretest and post-test scores of the experimental and control groups. The mean of the pretest scores of the experimental group was 38.71 and the post-test was 80.41 . The mean of the control group pretest scores was 36,003 and the post-test was 65.41 .

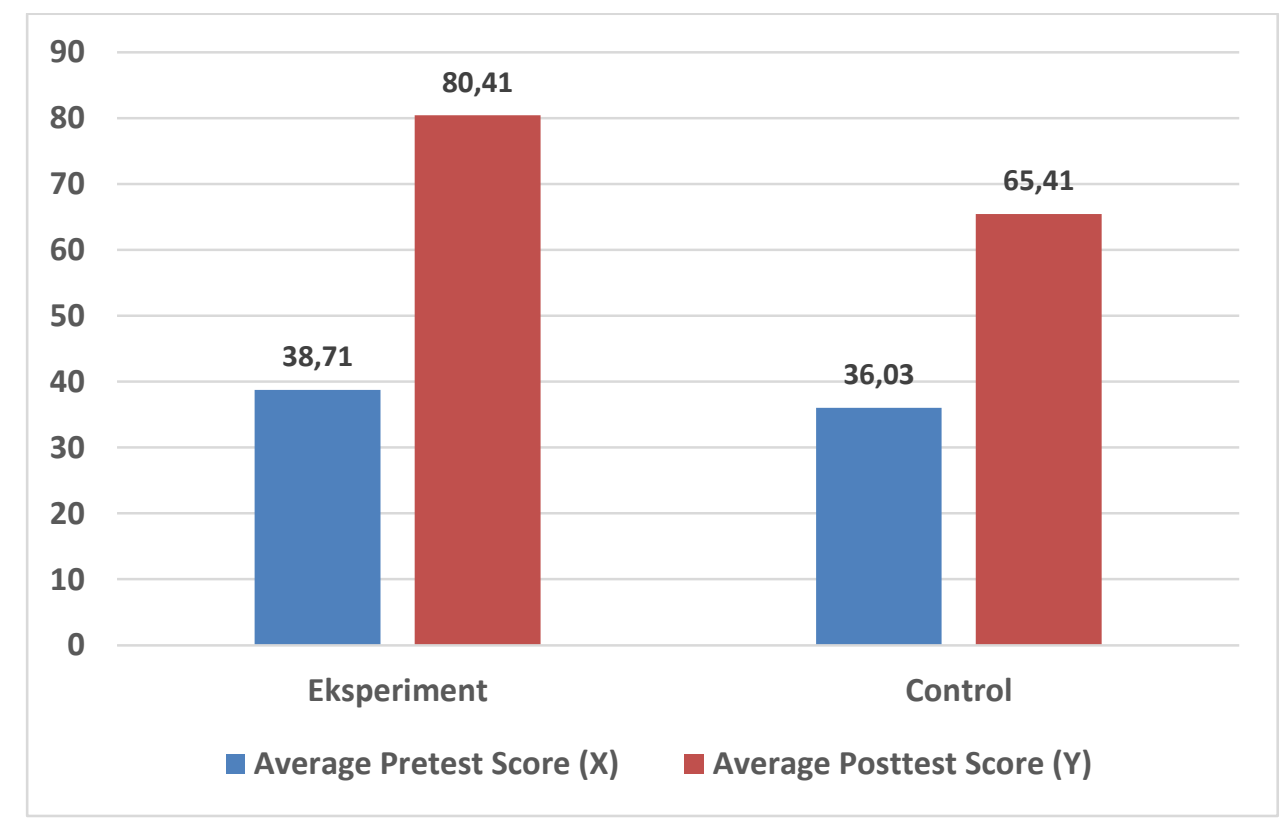

Figure-2. Pretest and Post-test scores of the Experimental and Control groups

The results of covariance analysis (ANCOVA) showed that experimental and control group students had insignificantly different abilities before treatment (pretest). Meanwhile, the results of the ANCOVA test on student learning outcomes in the experimental and control groups showed a significant difference (Table-3). It means that the application of chat room-based blended learning has a positive effect on student learning outcomes.

Table-3. Analysis of covariance data on the experimental and control groups learning outcomes. 
IJASOS- International E-Journal of Advances in Social Sciences, Vol. VII, Issue 19, April 2021

\begin{tabular}{|c|c|c|c|c|c|c|}
\hline $\begin{array}{l}\text { Source of } \\
\text { Variation }\end{array}$ & $\begin{array}{c}\text { Total } \\
\text { Squares }\end{array}$ & df & $\begin{array}{l}\text { Mean of } \\
\text { squares }\end{array}$ & F-count & $\begin{array}{c}\text { F-table }(0.05) \\
d f=1: 64)\end{array}$ & Conclusion \\
\hline Treatment & 3825.00 & 1 & 3825.00 & $\left.89.38^{*}\right)$ & 4.00 & $\begin{array}{l}\text { Significantly } \\
\text { different }\end{array}$ \\
\hline Pretest & 0.35 & 1 & 0.35 & $0.008^{\text {ns) }}$ & 4.00 & $\begin{array}{c}\text { Insignificantly } \\
\text { different }\end{array}$ \\
\hline Treatment-Pretest & 1.09 & 1 & 1.09 & $0.026^{\text {ni) }}$ & 4.00 & $\begin{array}{c}\text { Insignificantly } \\
\text { different }\end{array}$ \\
\hline Error & 2739.02 & 64 & 42.79 & & & \\
\hline Total & 6565.47 & 67 & & & & \\
\hline
\end{tabular}

Description: *) Significantly different.

ns) Insignificantly different.

The chat room-based blended learning model facilitated the online learning process to increase student learning motivation and increase learning outcomes.

Students often find it difficult to understand the human respiratory system because it is related to various supporting organs. The entry of air containing $\mathrm{O} 2$ and removing $\mathrm{CO} 2$ as residual oxidation involves the respiratory organs. In addition to face-to-face learning, online advanced learning through chat room-based blended learning is very effective in improving material understanding, learning outcomes, and creating more meaningful learning.

Several factors affect the quality of the learning process are conducive state of the student while studying, the preparation of educators, and the learning model used. Therefore, the application of the chat room-based blended learning model can improve the students' abilities to achieve the expected goals and obtain maximum learning outcomes. The post-test results showed the difference in learning outcomes between the experimental and control group students. The application of blended learning to the control group has proven unable to increase student participation and understanding; only a part of the control group students can understand the material, answer, argue, or complete the Student Worksheet (LKPD) properly so that their learning outcomes are not optimal.

Blended learning is a mixture of face-to-face and online learning to establish good communication between educators and students to improve learning outcomes effectively (Volchenkova, 2016). Blended learning is a combination of E-learning and classroom learning. This model implemented through the use of the internet and computers (or smartphones) allow teachers and students to communicate with each other in a special design to increase student motivation and learning outcomes (Kavitha and Jaisingh, 2018). Blended learning is flexible so that students can easily access updated resources (material) (Gorges, 2016).

\section{CONSLUSION AND SUGGESTION}

The application of the chat room-based blended learning model has a positive contribution to increasing student motivation and learning outcomes. The application of the chat room-based blended learning model has a good impact on increasing motivation and learning outcomes. However, this model has not been able to fully improve student motivation and learning outcomes, so there is a need for further studies on the chat room-based blended learning model to prevent low learning motivation which results in lower learning outcomes.

\section{REFERENCE LIST}

Aleksander, A.; Tomazevic, N.; Kerzic, D.\&Umek, L. (2017). The impact of demographic factors on selected aspects of e-learning in higher education. The International Journal of Information and Learning Technology, 34 (2):114-121. 
Alsalhi, N.R.; Eltahir, M.E.\& Al-Qatawneh, S.S. (2019). The effect of blended learning on the achievement of ninth grade students in science and their attitudes towards its use. Heliyon, 5(9):00-00.

Anonymous. (2018). Puspendik.Kemendikbud. Available in: https://hasilun.puspendik.kemdikbud.go.id/. (Accessed on 20 September 2019).

Chandra, V.; Fisher, D.L. (2009). Students' perceptions of a blended web-based learning environment. Learning Environment Research, 12(1):31-44.

Chen, C.C. \& Jones, K.T. (2007). Blended learning vs. traditional classroom settings: Assessing effectiveness and student perceptions in an MBA accounting course. The Journal of Educators Online, 4(1):1-15.

Dziuban, C.; Graham, C.R.; Moskal, P.D.; Norberg, A.\& Sicilia, N. (2018). Blended learning: the new normal and emerging technologies. International Journal of Educational Technology in Higher Education, 15(1): 0-3.

Eliseev, V.N. (2016). The development of cognitive independence of students of the University through networking cooperation. SHS Web of conferences. France, 29(0):1-5

Gall, M.D.; Gall,J.P \& Brog, W.R. 2003. Educational Research an Introduction. Boston: Pearson Education Inc.

Gorges, J. (2016). Why adults learn: Interpreting adults' reasons to participate in education in terms of Eccles' subjective task value. International Online Journal of Education and Teaching (IOJET), 3(1):26-41.

Gros, B., \& García-Peñalvo, F. J. (2016). Future trends in the design strategies and technological affordances of e-learning. In M. Spector, B. B. Lockee, \& M. D. Childress (Eds.), Learning, Design, and Technology. An International Compendium of Theory, Research, Practice, and Policy Switzerland: Springer International Publishing, 0(0): 1-23.

Hake, R.R. (2007). Interactive-engagement versus traditional methods: A six Thousand-student survey of mechanics test data for introductory physics courses. American Journal of Physics, 66(1):64-74.

Huang, C.S.; Yang, S. J.; Chiang, T. H.\& Su, A. Y. (2016). Effects of situated mobile learning approach on learning motivation and performance of EFL students. Journal of Educational Technology \& Society, 19(1):263-276.

Kavitha, R.; Jaisingh, W. (2018). A study on the student experiences in blended learning environments. Int. J. Recent Technol. Eng., 7(4):2277-3878.

Kintu, M. J.\& Zhu, C. (2016). Student characteristics and learning outcomes in a blended learning environment intervention in a Ugandan University. Electronic Journal of e-Learning, 14(3):181-195.

López-Pérez, M. V., Pérez-López, M. C., \& Rodríguez-Ariza, L. (2011). Blended learning in higher education: Students' perceptions and their relation to outcomes. Computers \& education, 56(3): 818-826.

Lu, O.H.; Huang, A.Y.; Huang, J.C.; Lin, A.J.; Ogata, H.\& Yang, S.J. (2018). Applying learning analytics for the early prediction of Students' academic performance in blended learning. Journal of Educational Technology \& Society, 21(2):220-232.

Manggabarani, A.F.; Sugiarti, S.\& Masri, M. (2016). Pengaruh Model Pembelajaran Blended Learning Terhadap Motivasi dan Hasil Belajar Siswa Kelas X SMA Negeri 1 Pitumpanua Kab. Wajo (Studi Pada Materi Pokok Sistem Periodik Unsur). Chemica: Jurnal IImiah Kimia dan Pendidikan Kimia, 17(2):83-93.

Rasmitadila, R., Widyasari, W., Humaira, M., Tambunan, A., Rachmadtullah, R., \& Samsudin, A. (2020). Using Blended Learning Approach (BLA) in Inclusive Education Course: A Study Investigating Teacher Students' Perception. International Journal of Emerging Technologies in Learning (IJET), 15(2):72-85.

Smyth, S., Houghton, C., Cooney, A., \& Casey, D. (2012). Students' experiences of blended learning across a range of postgraduate programmers. Nurse education today, 32(4):464-468.

Vanslambrouck, S.; Zhu, C.; Lombaerts, K.; Philipsen, B.\&Tondeur, J. (2018). Students' motivation and subjective task value of participating in online and blended learning environments. The Internet and Higher Education, 36(0):33-40.

Volchenkova, K. (2016). Blended learning: definition, models, implication for higher education. Educ. Sci. 8 
(2):24-30.

Yeh, Y.C., Huang, L.Y., \& Yeh, Y.L. (2011). Knowledge management in blended learning: Effects on professional development in creativity instruction. Computers \& Education, 56(1):146-156. 